\title{
Rapid induction of heparin-binding epidermal growth factor/diphtheria toxin receptor expression by Raf and Ras oncogenes
}

\author{
Sean A. McCarthy, ${ }^{1}$ Michael L. Samuels, ${ }^{1}$ Catrin A. Pritchard, ${ }^{1,3}$ Judith A. Abraham, ${ }^{2}$ \\ and Martin McMahon ${ }^{1,4}$ \\ ${ }^{1}$ DNAX Research Institute, Palo Alto, California 94304 USA; ${ }^{2}$ Scios Nova Inc., Mountain View, California 94043 USA
}

\begin{abstract}
We have used differential display PCR to search for mRNAs induced by $\triangle$ Raf-1:ER, an estradiol-dependent form of the Raf-1 kinase. Through this approach the gene encoding heparin-binding epidermal growth factor (HB-EGF) was identified as an immediate-early transcriptional target of oncogenic Raf kinases. Activation of $\Delta R a f-1: E R$ and a conditional oncogenic form of B-Raf, $\triangle B-R a f: E R$, resulted in rapid and sustained induction of HB-EGF mRNA expression and secretion of mature HB-EGF from cells. Neutralizing anti-HB-EGF antisera prevented the delayed activation of the c-Jun amino-terminal kinases that is observed in cells transformed by $\triangle R a f-1: E R$. These results demonstrate that distinct signaling pathways can cross talk via the secretion of polypeptide growth factors. Furthermore, cells transformed by oncogenic Ras, which also induced HB-EGF expression, demonstrated a marked increase in sensitivity to the cytotoxic action of diphtheria toxin, for which the membrane anchored HB-EGF precursor acts as a cell-surface receptor.
\end{abstract}

[Key Words: Ras; Raf; heparin-binding epidermal growth factor; c-Jun amino-terminal kinase; diphtheria toxin] Received June 5, 1995; revised version accepted July 7, 1995.

Genetic and biochemical studies have emphasized the importance of the Ras/Raf/MEK/MAP kinase signaling pathway in mediating diverse responses to extracellular stimuli in eukaryotes (Egan and Weinberg 1993; Nishida and Gotoh 1993; Sternberg et al. 1993; Dickson and Hafen 1994; Herskowitz 1995). Receptor-mediated activation of Ras leads to the sequential activation of Raf, MEK, and MAP kinases (Marshall 1994, 1995). The MAP kinases subsequently translocate to the nucleus where they effect the phosphorylation of specific transcription factors, leading ultimately to the modulation of gene expression (Hunter and Karin 1992; Hill et al. 1993; Hill and Treisman 1995; Karin 1994). Transcription factors targeted by the MAP kinases include Elk-1 in mammalian cells (Hill et al. 1993; Marais et al. 1993) and pointed and Yan in Drosophila (Brunner et al. 1994; O'Neill et al. 1994; Rebay and Rubin 1995).

The stress-activated/c-Jun amino-terminal protein $\mathrm{ki}$ nase (SAPK/JNK) pathway is a recently described kinase cascade with strong parallels to the MAP kinase pathway (Hibi et al. 1993; Derijard et al. 1994; Karin 1994; Kyriakis et al. 1994). Activation of this pathway by polypeptide factors involves sequential activation of MEKKl and

\footnotetext{
${ }^{3}$ Present address: Department of Genetics, Leicester University, Leicester, UK.

${ }^{4}$ Corresponding author.
}

the SAPK/JNK kinase SEK1, leading to phosphorylation and activation of the p46/p54 SAP/JUN kinases (hereafter referred to as JNKs) (Sanchez et al. 1994; Yan et al. 1994). Activated JNKs can phosphorylate both the c-Jun and ATF-2 transcription factors, thereby stimulating their trans-activation function (Derijard et al. 1994; Karin 1994; Kyriakis et al. 1994; Minden et al. 1994b; Gupta et al. 1995). Activation of the JNK pathway can be achieved through both Ras-dependent and -independent mechanisms, with the Ras-dependent route involving MEKKl (Lange-Carter et al. 1993; Derijard et al. 1994; Kyriakis et al. 1994; Lange-Carter and Johnson 1994; Sanchez et al. 1994; Su et al. 1994; Yan et al. 1994; Russell et al. 1995). Thus, growth factor-dependent activation of Ras stimulates at least two kinase cascades that act in parallel to regulate transcription factor activity.

Transfection of HeLa cells with constitutively active, oncogenic forms of Ras or Raf-1 results in constitutive activation of the MAP kinases and JNKs (Minden et al. 1994a). However, a temporal dissociation between MAP kinase and JNK activation has been demonstrated in cells expressing $\Delta$ Raf-1:ER, a conditional form of oncogenic Raf-1 regulated by the hormone-binding domain of the estrogen receptor (Minden et al. 1994a; Samuels et al. 1993). Whereas activation of MEK and the p42/p44 MAP kinases occurs within minutes of $\Delta$ Raf-1:ER activation and is independent of de novo protein synthesis, JNK 
activation is not observed until 16-24 hr later. Delayed JNK activation is thought to be mediated by release of autocrine factors, rather than direct cross talk between pathways, because conditioned medium from $\Delta$ Raf1:ER-transformed cells evokes rapid activation of JNKs when applied to naive cells (Samuels et al. 1993; Minden et al. 1994a; Samuels and McMahon 1994).

In view of the importance attributed to the regulation of gene expression in cellular responses to activation of the Ras/Raf/MEK/MAP kinase cascade, we have attempted to identify genes regulated by $\triangle$ Raf- $1: E R$ in NIH-3T3 cells using the technique of differential display PCR (Liang and Pardee 1992; Liang et al. 1993). One gene identified through this approach encodes heparin-binding epidermal growth factor (HB-EGF). HB-EGF is a member of the EGF family that signals through the EGF receptor and is mitogenic for many cell types (Higashiyama et al. 1991, 1992, 1993; Abraham et al. 1993; Hashimoto al. 1994; Ito et al. 1994). We show that the HB-EGF gene is an immediate-early transcriptional target of the conditional Raf kinases, $\triangle \mathrm{Raf}-\mathrm{1}: \mathrm{ER}$ and $\Delta \mathrm{B}$ Raf:ER, and that secreted HB-EGF mediates delayed activation of the JNKs in $\triangle$ Raf-1:ER-transformed cells. We also demonstrate that oncogenic Ras activates HB-EGF mRNA expression and that cells expressing oncogenic Ras display a marked increase in sensitivity to diphtheria toxin $(D T)$, for which the transmembrane HB-EGF precursor acts as a cell-surface receptor (Naglich et al. 1992a,b).

\section{Results \\ Identification of $H B-E G F$ as a $\triangle R a f-1: E R$-responsive gene}

Differential display PCR of mRNAs extracted from NIH$3 T 3$ cells expressing $\triangle$ Raf-1:ER (3T3 $\Delta$ Raf-1:ER) led to the identification of a PCR product of $\sim 270$ bp that was amplified consistently from cells treated for $4 \mathrm{hr}$ with an activator of $\triangle$ Raf-1:ER, ICI 164,384 (ICI), but not control cells (Fig. 1A). Cloning and sequencing of this DNA fragment revealed a cDNA of $263 \mathrm{bp}$ (termed 14G1) with extensive homology to the extreme 3 ' end of the human cDNA encoding HB-EGF (Higashiyama et al. 1991) (Fig. 1B). Overall identity of the mouse 14G1 cDNA with the homologous region of human HB-EGF was $74 \%$ including complete conservation of a putative mRNA destabilization motif and a consensus polyadenylation signal. Activation of 14G1 mRNA expression by $\triangle$ Raf-1:ER was subsequently confirmed by RNase protection analysis. As shown in Figure 1C, the steady-state level of 14G1 mRNA in quiescent 3 T3 3 Raf-1:ER cells was elevated

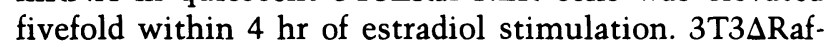
1:ER cells stimulated for $4 \mathrm{hr}$ with ICI, which activates $\Delta$ Raf-1:ER with similar kinetics to estradiol (Samuels et al. 1993), demonstrated a comparable increase in 14G1 mRNA expression (Fig. 1D). ICI treatment had no effect on 14G1 mRNA expression in parental NIH-3T3 cells, confirming that the response requires the activity of the $\triangle$ Raf-1:ER fusion protein. We subsequently confirmed that $14 \mathrm{Gl}$ represented the 3 ' end of the mouse HB-EGF cDNA by sequencing a full-length murine HB-EGF clone (gift of M. Klagsbrun, Harvard Medical School, Boston, MA). Subsequent RNase protection analyses were performed with a probe complementary to the murine $\mathrm{HB}-$ EGF-coding sequence.

\section{Regulation of HB-EGF mRNA expression by distinct Raf kinases}

Three mammalian Raf kinases have been described, Raf1, A-Raf, and B-Raf (Morrison 1990; Rapp 1991). We therefore investigated the responsiveness of HB-EGF mRNA expression to conditional, oncogenic forms of each (C.A. Pritchard, M.L. Samuels, E. Bosch, and M. McMahon, in prep.). As shown in Figure 2A, activation of $\triangle$ Raf-1:ER in NIH-3T3 cells led to rapid induction of HB-EGF mRNA expression, first apparent after $1 \mathrm{hr}$ of stimulation. Induction reached a maximum of 14 -fold over the resting level within $8 \mathrm{hr}$ and was maintained at $24 \mathrm{hr}$. Activation of $\triangle \mathrm{B}-\mathrm{Raf}: \mathrm{ER}$ in NIH-3T3 cells also resulted in rapid and sustained elevation of HB-EGF mRNA expression, which reached eightfold over the basal level within $2 \mathrm{hr}$ and was maintained at $24 \mathrm{hr}$ (Fig. 2B). Activation of $\triangle \mathrm{A}-\mathrm{Raf}: \mathrm{ER}$ in NIH-3T3 cells led to only a transient twofold increase in HB-EGF mRNA expression (Fig. 2C).

Transformation of Ratla cells by $\triangle$ Raf- 1 :ER occurs in the absence of detectable $\mathrm{p} 42 / \mathrm{p} 44$ MAP kinase activation (Gallego et al. 1992; Gupta et al. 1992; Samuels et al. 1993). In these cells HB-EGF mRNA expression was also induced sevenfold but not until 8-24 hr after $\Delta$ Raf1:ER activation (Fig. 2D). Thus, cell type-specific differences may exist in the elements between $\triangle$ Raf-1:ER activation and increased HB-EGF mRNA expression.

\section{Mechanism of activation of $H B-E G F$ mRNA expression} by $\triangle R a f-1: E R$ and $\triangle B-R a f: E R$

We next investigated the mechanism by which activation of $\triangle$ Raf-1:ER and $\triangle B-R$ af:ER leads to increased expression of HB-EGF mRNA. First, the dependence of HB-EGF mRNA induction on de novo protein synthesis was tested. $3 T 3 \Delta$ Raf-1:ER and $3 T 3 \Delta B-R$ af:ER cells were stimulated with ICI or serum in either the absence or presence of the protein synthesis inhibitor cycloheximide, as indicated in Figure $3 \mathrm{~A}$. Activation of either $\triangle \mathrm{Raf}-$ 1:ER or $\triangle B-R a f: E R$ led to induction of HB-EGF mRNA expression (Fig. 3A, lanes $1,2,7$, and 8 , respectively). Serum stimulation also induced HB-EGF mRNA expression in both cell lines, consistent with previous reports of this gene's responsiveness to a variety of external signals (Temizer et al. 1992; Yoshizumi et al. 1992; Dluz et al. 1993; Morita et al. 1993; Nakano et al. 1994, Perrella et al. 1994; Tan et al. 1994 (Fig. 3A, lanes 3,9). Cycloheximide treatment alone led to induction of HB-EGF mRNA expression in both cell lines (Fig. 3A, lanes 4,10). Activation of either $\Delta$ Raf-1:ER or $\triangle \mathrm{B}-\mathrm{Raf}: \mathrm{ER}$, or serum 


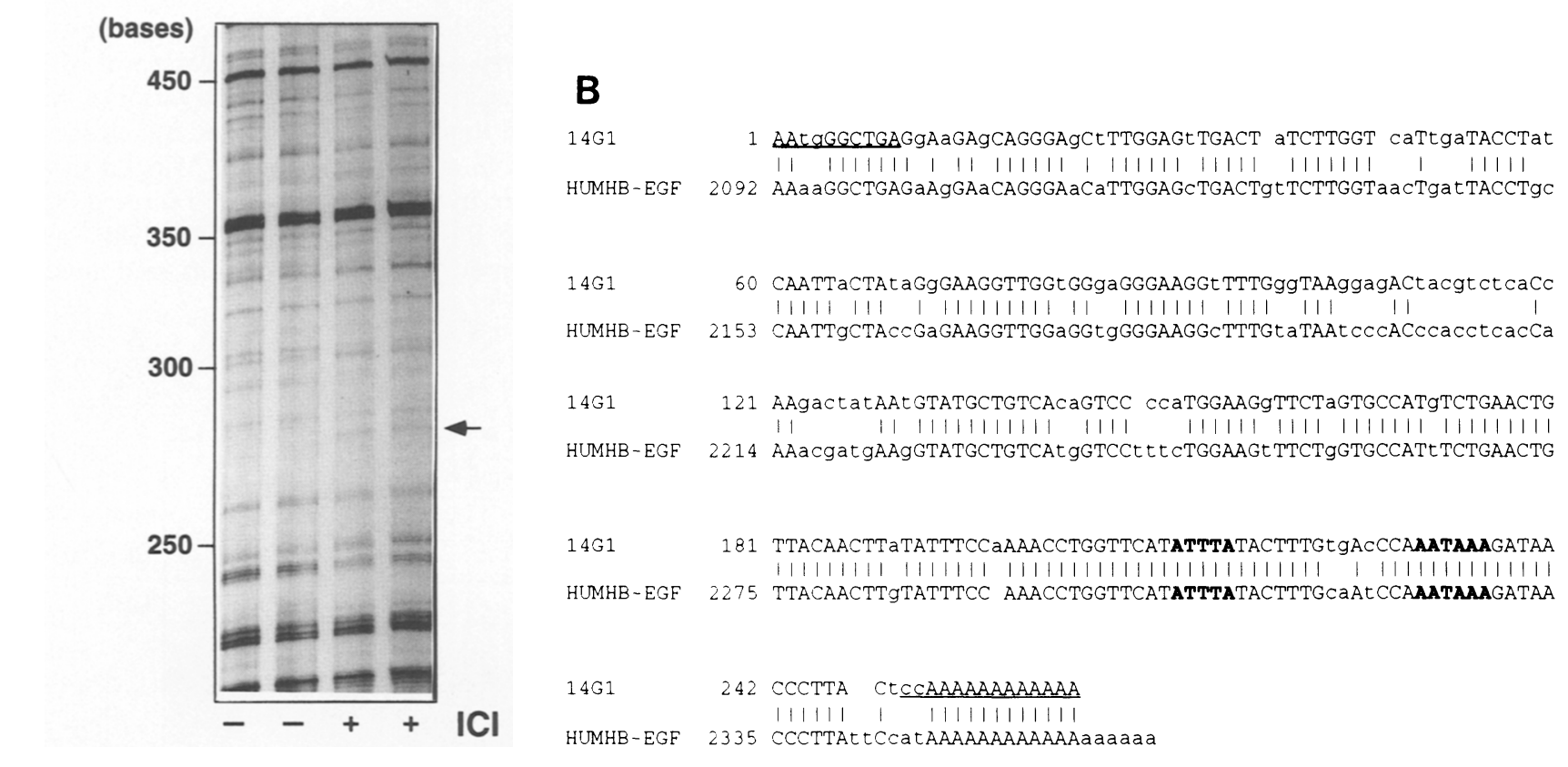

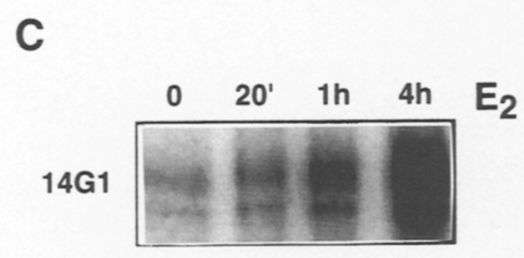

GAPDH

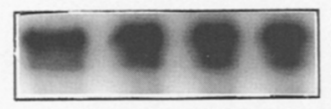

D

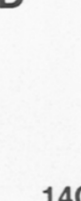

$14 \mathrm{G1}$ 3T3
$\Delta$ Raf-1:ER

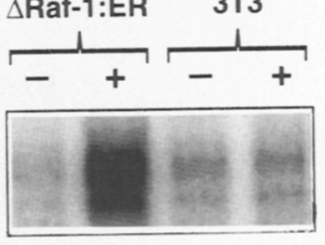

GAPDH

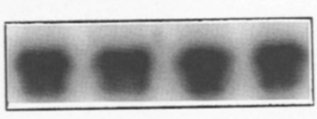

Figure 1. Identification of $\mathrm{HB}-\mathrm{EGF}$ as a $\triangle \mathrm{Raf}$ 1:ER-responsive gene. $(A)$ Duplicate PCR amplifications were conducted on RNA isolated from 3 T $3 \Delta$ Raf-1:ER cells treated for $4 \mathrm{hr}$ either with $0.1 \%(\mathrm{vol} / \mathrm{vol})$ ethanol as a solvent control $(-)$ or $1 \mu \mathrm{M}$ ICI $(+)$ and the products analyzed by denaturing polyacrylamide gel electrophoresis. Primers used in these reactions were AP14 and $T_{12} M G$. The arrow indicates the amplified 14Gl fragment. The positions of molecular weight markers are indicated. $(B)$ Sequence comparison of the 14Gl cDNA to the human HB-EGF cDNA. The AP14 and $T_{12}$ MG primers are underlined. Lowercase letters refer to mismatches between the human and mouse sequences. The conserved mRNA destabilization motif (ATTTA) and polyadenylation signal (AATAAA) are emboldened. (C) Activation of 14Gl mRNA expression by $\triangle$ Raf-1:ER. RNA samples were prepared from 3T3 $\Delta$ Raf-1:ER cells at different times after treatment with $1 \mu \mathrm{M} \beta$-estradiol $\left(E_{2}\right)$ as indicated. HB-EGF and GAPDH mRNA expression were quantitated simultaneously by RNase protection as described in Materials and methods. $(D)$ RNase protection analysis of $14 \mathrm{G} 1 \mathrm{mRNA}$

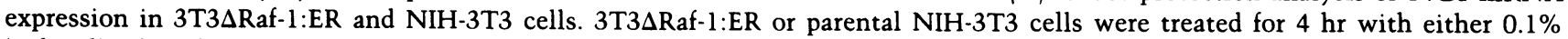
(vol/vol) ethanol as a solvent control $|-|$ or $1 \mu \mathrm{M} \mathrm{ICI}|+|$ as indicated. 14Gl and GAPDH mRNA expression were quantitated simultaneously by RNase protection.

stimulation in the presence of cycloheximide, however, resulted in superinduction of HB-EGF mRNA expression above the level induced by cycloheximide alone (Fig. 3A, lanes 5,6,11,12). Thus, HB-EGF mRNA induction by $\triangle \mathrm{Raf}-1: \mathrm{ER}, \triangle \mathrm{B}-\mathrm{Raf}: \mathrm{ER}$, and serum occurs in the absence of de novo protein synthesis and can therefore be categorized as an immediate-early response to these stimuli (Almendral et al. 1988; Yoshizumi et al. 1992; Herschman 1991; Dluz et al. 1993; Barnard et al. 1994).

To determine whether increased HB-EGF mRNA expression resulted from increased transcription of the HB-EGF gene, nuclear run-on transcription assays were performed. Stimulation of quiescent 3T3 BB-Raf:ER cells for $3 \mathrm{hr}$ with ICI resulted in a fourfold increase in run-on HB-EGF transcripts relative to control cells (Fig. 3B). A twofold increase in transcription of the c-fos gene, which we have shown to be responsive to $\triangle \mathrm{Raf}-1$ :ER (S. McCarthy, unpubl.), was also observed under these conditions. Similar induction of HB-EGF transcription was detected following activation of $\triangle$ Raf-1:ER (data not shown). The half-life of HB-EGF mRNA was also measured and found to be similar in control and ICI-stimulated cells /data not shown). Thus, maintained elevation of HB-EGF mRNA expression in response to $\triangle \mathrm{Raf}-1: \mathrm{ER}$ activation requires continued gene transcription and does not appear to involve a significant change in mRNA stability. 
A

3T3 $\triangle$ Raf-1:ER

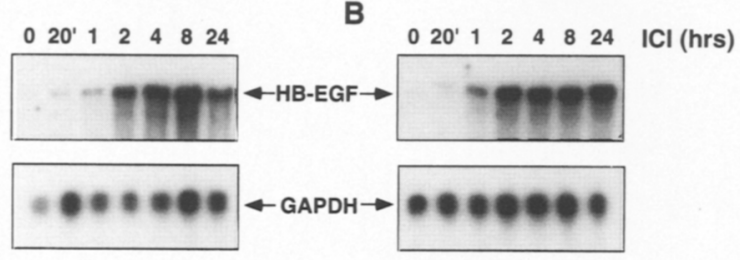

C

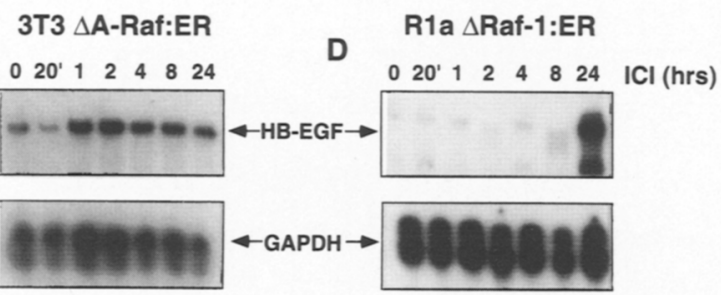

Figure 2. Induction of HB-EGF mRNA expression by different Raf kinases. NIH-3T3 cells expressing either $\Delta$ Raf-1:ER $(A), \Delta B$ Raf:ER $(B)$, or $\Delta$ A-Raf:ER $(C)$ or Rat la cells expressing $\Delta$ Raf1:ER $(D)$ were treated with $1 \mu \mathrm{M}$ ICI for the indicated times. HB-EGF and GAPDH mRNA expression were analyzed simultaneously by RNase protection as described in Materials and methods.

\section{Characterization of $H B-E G F$ protein secretion from $\triangle R$ af-1:ER-transformed cells}

To investigate whether induction of HB-EGF mRNA resulted in increased secretion of soluble HB-EGF protein, NIH-3T3 cells expressing $\triangle$ Raf-1:ER were pulse-labeled with $\left[{ }^{35} \mathrm{~S}\right]$ methionine/cysteine. Labeled proteins were chased into serum-free medium, ethanol precipitated, and analyzed by two-dimensional polyacrylamide gel electrophoresis (Fig. 4A). Activation of $\Delta$ Raf-1:ER resulted in a significant increase in secretion of a protein of $\sim 17 \mathrm{kD}$ compared to control cells. The major $\Delta \mathrm{Raf}-1$ :ERinduced species was of pI 6.9, similar to that of human HB-EGF, which has an apparent molecular weight of 19-23 kD and an isoelectric point of 7.2-7.8 (Higashiyama et al. 1992). The induced protein migrated over a considerable pI range (pI 5.8-7.5), which may reflect heterogeneous $O$-linked glycosylation (Higashiyama et al. 1992). To confirm the identity of the induced $17-\mathrm{kD}$ species as HB-EGF, conditioned media were collected from cells expressing $\Delta$ Raf-1:ER. Secreted proteins were adsorbed onto heparin-Sepharose and analyzed for the presence of HB-EGF by Western blotting with a specific antiserum. In accord with the two-dimensional analysis, activation of $\triangle$ Raf-1:ER led to a three- to fourfold increase in the level of secreted HB-EGF found in conditioned media (Fig. 4B). Thus, activation of $\triangle$ Raf-1:ER in NIH-3T3 cells stimulated the secretion of mature HBEGF protein. Increased levels of HB-EGF protein were also detected in conditioned medium of cells transformed by $\triangle B$-Raf:ER, and increased HB-EGF mRNA and protein expression were observed in NIH-3T3 cells expressing constitutively active, oncogenic Raf-1 (data not shown).
$H B-E G F$ secretion is required for INK activation in cells transformed by $\triangle R a f-1: E R$

Activation of $\Delta$ Raf-1:ER in NIH-3T3 cells results in rapid, protein synthesis-independent activation of MEK and MAP kinase activity. In contrast, activation of the JNKs is delayed and thought to be mediated by release of an autocrine factor (Samuels et al. 1993; Minden et al. 1994a). We therefore investigated whether secreted HBEGF contributes to JNK activation in $\triangle$ Raf-1:ER- and $\Delta B-R a f: E R$-transformed cells. First, conditioned media

A $\begin{array}{llllllllllll}1 & 2 & 3 & 4 & 5 & 6 & 7 & 8 & 9 & 10 & 11 & 12\end{array}$

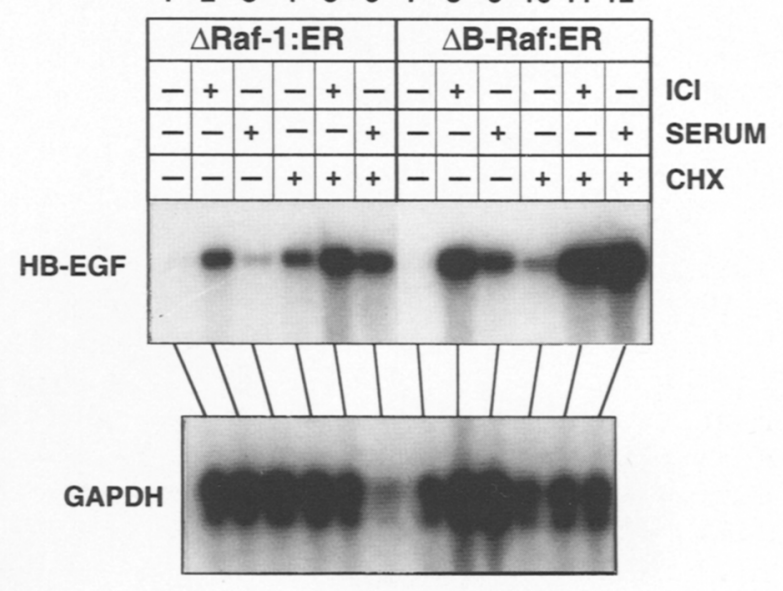

B

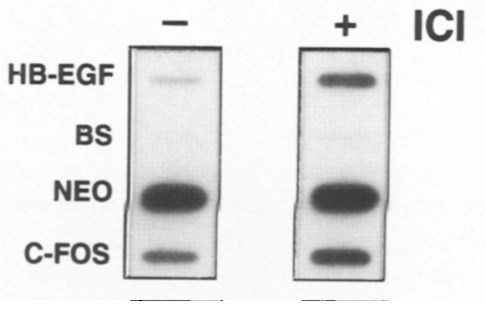

Figure 3. The HB-EGF gene is an immediate-early transcriptional target of $\Delta$ Raf-1:ER and $\triangle B$-Raf:ER. $(A)$ Induction of $\mathrm{HB}-$ EGF mRNA is insensitive to cycloheximide. NIH-3T3 cells expressing $\triangle \mathrm{Raf}-\mathrm{l}: \mathrm{ER}$ or $\triangle \mathrm{B}-\mathrm{Raf}: \mathrm{ER}$, cultured in media containing $0.5 \%$ FCS serum, were either untreated or treated for $1 \mathrm{hr}$ with $25 \mu \mathrm{g} / \mathrm{ml}$ of cycloheximide ( $\mathrm{CHX}$ ) as indicated. These cells were then either untreated, treated with $1 \mu \mathrm{M} \mathrm{ICI}$ for $4 \mathrm{hr}$ or $20 \%$ (vol/ vol) FCS for $1 \mathrm{hr}$ as indicated. HB-EGF and GAPDH mRNA expression were analyzed simultaneously by RNase protection. (B) Activation of HB-EGF transcription by $\triangle \mathrm{B}$-Raf:ER. NIH-3T3 cells expressing $\triangle \mathrm{B}-\mathrm{Raf}: \mathrm{ER}$ cultured in media containing $0.5 \%$ FCS were treated with either $0.1 \%(\mathrm{vol} / \mathrm{vol})$ ethanol as a solvent control $(-)$ or $1 \mu \mathrm{M} \mathrm{ICI}|+|$ for $3 \mathrm{hr}$ at which time cell nuclei and runoff transcripts were prepared as described in Materials and methods. Runoff transcripts were hybridized to filter-immobilized plasmid DNAs containing the indicated cDNA inserts. (HB-EGF) Full-length murine HB-EGF cDNA; (BS) pBluescript control; (NEO) full-length neomycin resistance cDNA; (C-FOS) full-length murine c-fos cDNA. neo is constitutively expressed from the retroviral vector expressing $\Delta \mathrm{B}-\mathrm{Raf}$ :ER (Samuels et al. 1993). 
A
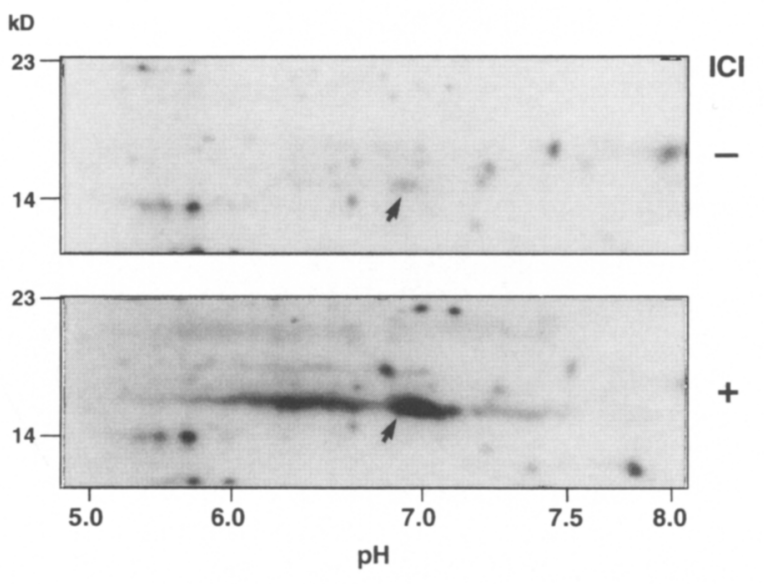

from $\triangle \mathrm{Raf}-1$ :ER and $\triangle \mathrm{B}$-Raf:ER-transformed cells were tested for their abilities to activate MAP kinases and INKs when applied to naive NIH-3T3 cells using myelin basic protein (MBP) and glutathione $S$-transferase (GST)c-Jun, respectively, as substrates. Whereas conditioned media from control cells were without effect (Fig. 5A, lanes 1,7), media from $\Delta$ Raf-1:ER- and $\Delta \mathrm{B}$-Raf:ER-transformed NIH-3T3 cells evoked coordinate activation of both MAP kinases and JNKs (Fig. 5A, lanes 2,8). Prior
B

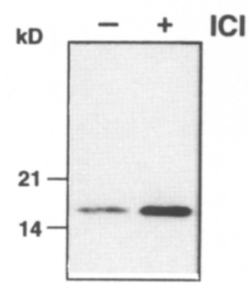

Figure 4. Activation of HB-EGF secretion by $\Delta$ Raf-1:ER. (A) 3T3 $\Delta$ Raf-1:ER cells were either untreated $(-)$ or treated with $1 \mu \mathrm{M} \mathrm{ICI}$ for $1 \mathrm{hr}$ $1+1$, at which time the cells were pulse labeled with $\left[{ }^{35} \mathrm{~S}\right]$ methionine/cysteine for $6 \mathrm{hr}$ and chased with DMEM containing methionine and cysteine for an additional $19 \mathrm{hr}$. Conditioned media were collected and analyzed by two-dimensional polyacrylamide gel electrophoresis as described in Materials and methods. The arrow indicates the location of HB-EGF. (B) 3T3 3 Raf1 :ER cells cultured in medium containing $0.5 \%$ (vol/vol) FCS were either untreated $(-)$ or treated with $1 \mu \mathrm{M} \mathrm{ICI}(+)$ for $36 \mathrm{hr}$ and the cell conditioned media was collected. HB-EGF in the conditioned media was adsorbed onto heparin-sepharose, solubilized by boiling in SDS-sample buffer, electrophoresed through a $14 \%$ (wt/vol) polyacrylamide gel and Western blotted. HBEGF expression was quantitated by probing this Western blot with an anti-HB-EGF antiserum (197).

depletion of heparin-binding factors by incubation with heparin-Sepharose significantly abrogated the abilities of the conditioned media to activate the MAP kinases and JNKs (Fig. 5A, lanes 5,11). Moreover, two specific neutralizing anti-HB-EGF antisera, but not a matched preimmune antiserum, also abrogated MAP kinase and JNK activation (Fig. 5A, lanes 3,4,6,9,10,12). The specificity of the antisera for neutralization of HB-EGF over other members of the EGF family has been described

A
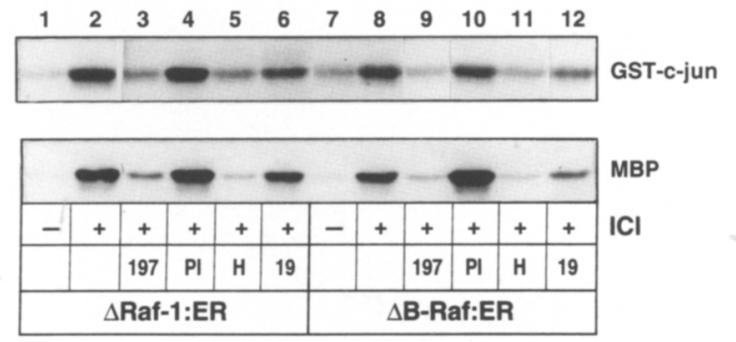

B

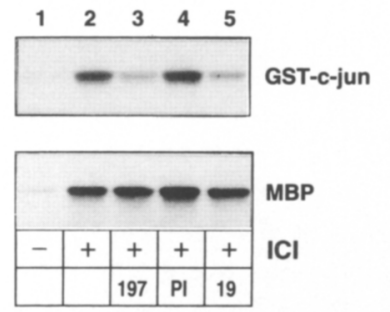

C

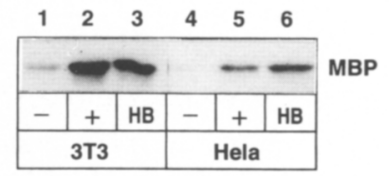

Figure 5. Activity of HB-EGF secreted by $3 T 3 \Delta$ Raf-1:ER and 3T3 $\Delta B-R a f: E R$ cells. $(A)$ Coordinate activation of p42 MAP kinase and JNKs in NIH-3T3 cells by conditioned media. Conditioned media were collected from 3T3 $\Delta$ Raf-1:ER and 3T3 $\Delta B$-Raf:ER cells that were either untreated $(-)$ or treated with $1 \mu \mathrm{M}$ ICI for $36 \mathrm{hr}(+)$. These conditioned media were then either untreated (lanes $1,2,7,8)$ or incubated with neutralizing anti-human HB-EGF antiserum (197), neutralizing anti-rat HB-EGF antiserum (19), a preimmune serum that was matched to serum 19 (PI) or depleted with heparin-Sepharose $(\mathrm{H})$, as indicated. Treated conditioned media were then applied to parental NIH-3T3 cells for 10 min at which time the activity of the JNKs and p42 MAP kinase in cell extracts were measured with GST-c-Jun and MBP, respectively, as substrates as described in Materials and methods. $(B)$ Anti-HB-EGF antisera abrogate JNK

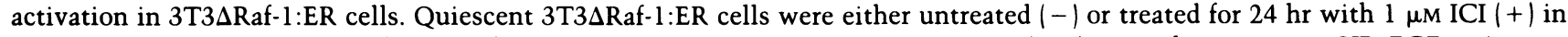
either the absence or presence of $100 \mu \mathrm{l}$ of neutralizing anti-human HB-EGF antiserum (197), neutralizing anti-rat HB-EGF antiserum (19) or a preimmune serum (PI) that was matched to serum 19, as indicated. Cell extracts were prepared and the activity of the JNKs and $\mathrm{p} 42$ MAP kinase measured as described above. $(C)$ Comparison of p42 MAP kinase activation by $3 T 3 \Delta$ Raf- 1 :ER cell conditioned media and recombinant human HB-EGF. Conditioned medium from 3 T3 3 Raf- 1 :ER cells either untreated $(-)$ or treated with ICI for $24 \mathrm{hr}(+)$ or medium supplemented with $2 \mathrm{ng} / \mathrm{ml}$ recombinant human HB-EGF (HB) were applied to NIH-3T3 (lanes 1-3) or HeLa (lanes 4-6) cells for 10 min at which time p42 MAP kinase activity was measured as described above. 
previously (Blotnick et al. 1994; Hashimoto et al. 1994; B. Garrick and J. Abraham, unpubl.). The anti-HB-EGF antibodies differed in their abilities to neutralize the activities of the conditioned media; antiserum 197 blocked in excess of $90 \%$ of the stimulatory activity, whereas antiserum 19 caused only a $30 \%-50 \%$ reduction. These differences appear to reflect different affinities for mouse HB-EGF of the antisera, which were raised against human (197) and rat (19) HB-EGF, respectively (Hashimoto et al. 1994; M. Samuels, unpubl.).

The experiments described above suggested that secretion of HB-EGF might account for the ability of conditioned media from $\triangle \mathrm{Raf}-1$ :ER- and $\triangle \mathrm{B}-\mathrm{Raf}$ :ER-transformed cells to activate the MAP kinases and JNKs when applied to naive NIH-3T3 cells. To determine whether autocrine stimulation of JNK activity in $\triangle$ Raf-1:ERtransformed cells is mediated by secreted HB-EGF, neutralizing antisera or preimmune antiserum was added to 3T3 Raf-1:ER cells simultaneously with ICI. MAP kinase and JNK activities were then measured $24 \mathrm{hr}$ later. Consistent with the results in Figure 5A, both anti-HBEGF antibodies tested, but not preimmune control antiserum, inhibited the autocrine activation of JNKs in $\Delta$ Raf-1:ER-transformed cells (Fig. 5B). Neither antibody, however, had any effect on MAP kinase activation in these cells (Fig. 5B). To determine whether HB-EGF secretion was sufficient for autocrine INK activation, the concentration of HB-EGF in $\triangle$ Raf-1:ER-transformed cell-conditioned medium was estimated by comparative Western blotting of heparin-adsorbed material from conditioned medium and serial twofold dilutions of recombinant human HB-EGF. The HB-EGF concentration of the conditioned medium was estimated to be $2 \mathrm{ng} / \mathrm{ml}$ (data not shown). As shown in Figure 5C, stimulation of either naive NIH-3T3 or HeLa cells with $2 \mathrm{ng} / \mathrm{ml}$ of purified recombinant human HB-EGF resulted in comparable p42 MAP kinase activation to that evoked by conditioned medium. Thus, secreted HB-EGF appears to be sufficient for autocrine activation of signaling pathways in Raf-transformed cells.

Oncogenic p21 $1^{\text {Ha-Ras }}$ activates $H B-E G F$ mRNA expression

Raf kinases play an essential role in the propagation of signals from activated Ras proteins to the MEK/MAP kinase signaling module. We therefore investigated whether $\mathrm{p} 21^{\mathrm{Ha}-\mathrm{R} a s}$ also influenced HB-EGF mRNA expression. To address the potential of $\mathrm{p} 21^{\mathrm{Ha}-\mathrm{Ras}}$ to induce HB-EGF, we utilized stable Ratl and NIH-3T3 cell lines in which the expression of activated H-Ras(V12) is regulated by the Escherichia coli lac repressor (Rat1:iRas and 3T3:iRas). Addition of IPTG to these cells results in rapid induction of $\mathrm{H}-\mathrm{Ras}(\mathrm{V} 12)$ protein expression detectable within $4 \mathrm{hr}$ of stimulation (Fig. 6A,B). Activation of Raf-1, MEK, and MAP kinases ensues (M. Samuels, unpubl.), and both cell lines display profound morphological transformation $24-48 \mathrm{hr}$ after IPTG addition (see Fig. 7A). Induction of $\mathrm{H}-\mathrm{Ras}(\mathrm{V} 12)$ expression in either Rat1:iRas or 3T3:iRas cells led to rapid induction of HB-
EGF mRNA expression (Fig. 6, C and D, respectively). The mRNA responses were apparent as early as $2-4 \mathrm{hr}$ after addition of IPTG, correlating with the time course of $\mathrm{H}-\mathrm{Ras}(\mathrm{V} 12)$ protein expression and suggesting strongly that the responses are a direct consequence of H-Ras(V12) expression. Maximal HB-EGF mRNA induction of six- to sevenfold was observed in each cell type 8 hr after addition of IPTG.

\section{DT sensitivity of Rat1 cells transformed by H-Ras(V12)}

The transmembrane precursor of HB-EGF recently has been shown to act as a cell-surface receptor for DT $(\mathrm{Na}$ glich et al. 1992a,b). DT is composed of a receptor-binding B-subunit and catalytic A-subunit. Receptor-dependent internalization of the toxin is followed by activation of the catalytic activity of the A-subunit, which ADP-ribosylates elongation factor-2, causing abrupt inhibition of protein synthesis and eventual cell death (Pappenheimer 1977; Middlebrook and Dorland 1984). Because certain oncogenically transformed cell lines have been shown to be more sensitive to DT than their normal counterparts (Buzzi and Maistrello 1973; Iglewski and Rittenberg 1974; Iglewski et al. 1975; Taylor and Iglewski 1979), we tested whether induction of H-Ras(V12) expression, which leads to increased expression of HB-EGF mRNA, altered the sensitivity of cells to DT-mediated killing (Fig. 7A). Ratl:iRas cells were induced to express H-Ras(V12) by treatment with IPTG, in either the absence or presence of DT $(200 \mathrm{ng} / \mathrm{ml})$. In the absence of $\mathrm{H}$-Ras(V12) expression the cells displayed a flat, nontransformed morphology, whereas cells treated

\section{Rat-1:iRas 3T3:iRas}

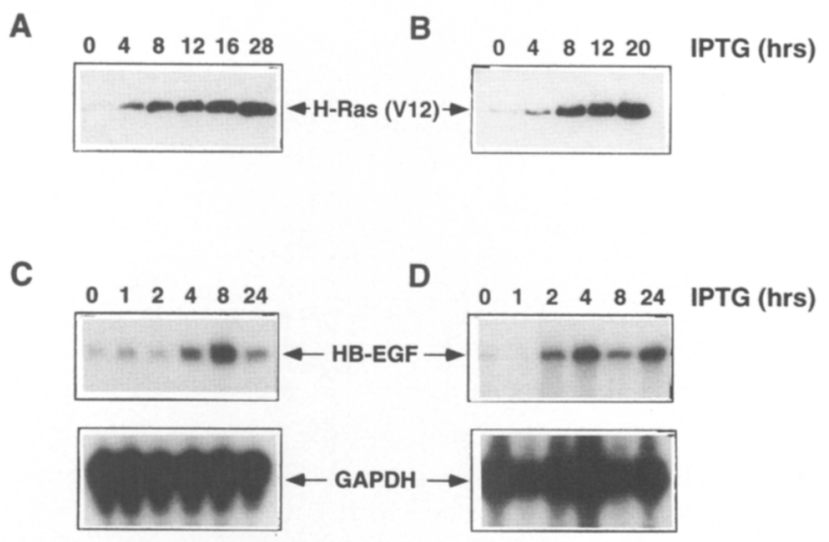

Figure 6. Induction of HB-EGF mRNA expression by H-Ras(V12). $(A, B)$ Ratl and NIH-3T3 cells containing an IPTGinducible H-Ras(V12) gene (Ratl:iRas and 3T3:iRas, respectively) were treated with $5 \mathrm{~mm}$ IPTG for the indicated times at which time the level of expression of the H-Ras(V12) protein was assessed by Western blotting of cell extracts with an antiRas antibody. $\{C, D \mid$ RNase protection analysis of HB-EGF and GAPDH mRNA expression in Rat1:iRas and 3T3:iRas cells following induction of $\mathrm{H}-\mathrm{Ras}(\mathrm{V} 12)$ expression with $5 \mathrm{mM}$ IPTG for the indicated times. 
A
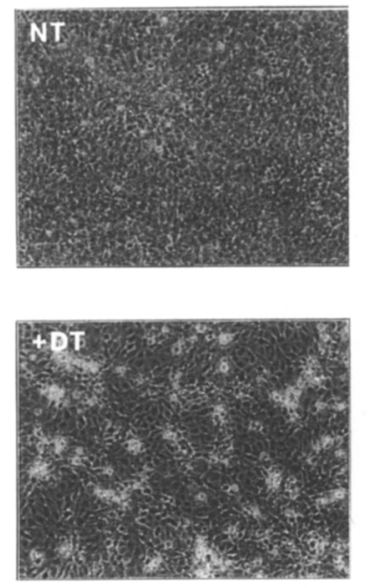
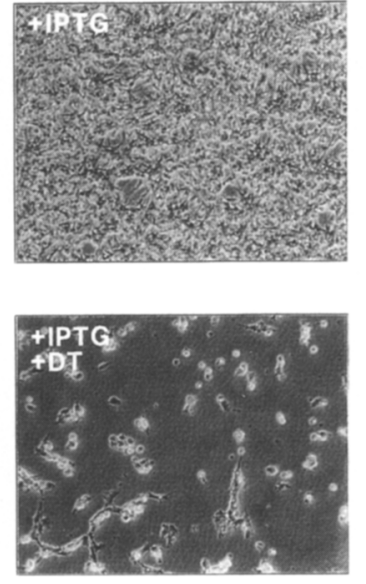

B

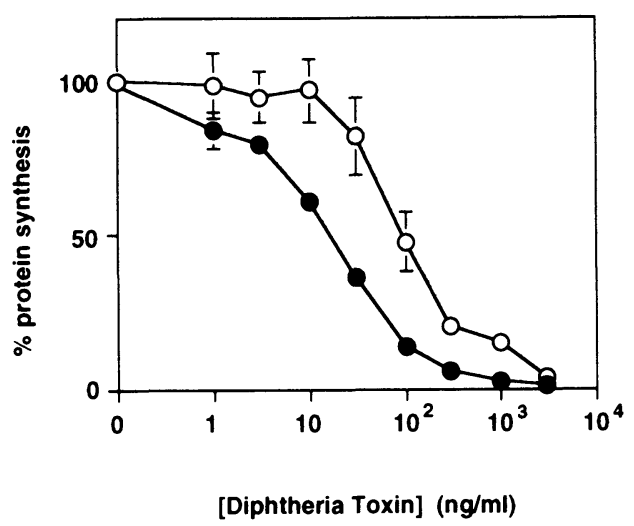

C

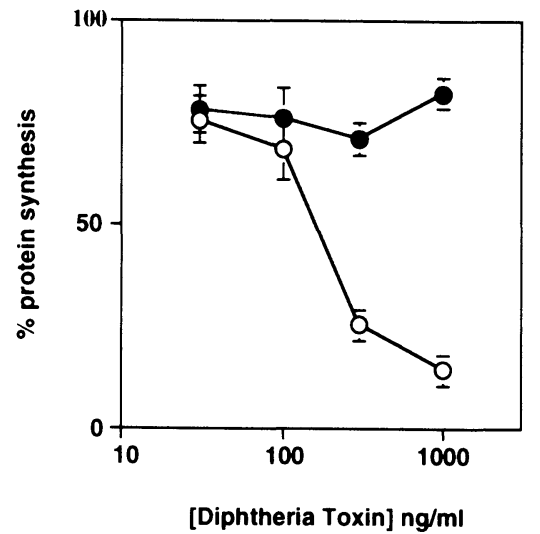

Figure 7. Cytotoxicity of DT for Ratl cells expressing H-Ras(V12). (A) Ratl:iRas cells were either untreated (NT) or treated with $5 \mathrm{~mm}$ IPTG in the absence or presence of 200 $\mathrm{ng} / \mathrm{ml} \mathrm{DT}$ as indicated. Cells were incubated for $48 \mathrm{hr}$ at which time they were photographed with a Nikon TMS microscope and a Polaroid camera (on signal magnification, $79 \mathrm{x}) .(B)$ Dose-response curves for inhibition of protein synthesis by DT in control $(O)$ and IPTG-treated (O) Rat l:iRas cells. Cells were either untreated or treated with $5 \mathrm{~mm}$ IPTG to induce the expression of H-Ras(V12). DT was added $24 \mathrm{hr}$ later at the indicated concentrations. After an additional 14 - $\mathrm{hr}$ incubation, cellular protein synthesis was measured by incorporation of $\left[{ }^{3} \mathrm{H}\right]$ leucine as described in Materials and methods. Each point represents the mean of six separate determinations \pm S.E.M. $(C)$ Inhibition of DT cytotoxicity by CRM197. Rat 1 :iRas cells were treated with $5 \mathrm{mM}$ IPTG together with the indicated concentrations on DT in either the absence or presence of $200 \mu \mathrm{g} / \mathrm{ml} \mathrm{CRM} 197$. After $15 \mathrm{hr}$ cellular protein synthesis was measured by incorporation of $\left[{ }^{3} \mathrm{H}\right] \mathrm{leucine}$. Each point represents the mean of six separate determinations \pm S.E.M. for $48 \mathrm{hr}$ with IPTG displayed a characteristic highly transformed morphology. Cells treated with DT in the absence of IPTG demonstrated little obvious toxin sensitivity, as judged by the presence of an intact cell monolayer and few dead cells. However, induction of $\mathrm{H}-\mathrm{Ras}(\mathrm{V} 12)$ expression in the presence of DT resulted in the death of $>95 \%$ of the cells. Dose-response experiments indicated that $\mathrm{H}$-Ras(V12)-expressing cells were at least 50 -fold as sensitive to DT-mediated killing as uninduced cells (data not shown). Similar results were obtained with Rat la cells expressing $\Delta$ Raf-1:ER (data not shown). To determine whether increased DT sensitivity resulted from increased toxin uptake, inhibition of protein synthesis by DT was measured. Protein synthesis in uninduced Rat 1:iRas cells was inhibited by DT in a dosedependent manner, indicating that these cells display basal sensitivity to the toxin $\left(\mathrm{IC}_{50}=100 \mathrm{ng} / \mathrm{ml}\right)$. However, protein synthesis in IPTG-treated Ratl:iRas cells was inhibited by substantially lower doses of DT $\left(\mathrm{IC}_{50}=17 \mathrm{ng} / \mathrm{ml}\right.$ ) (Fig. 7B). This constitutes a sixfold increase in sensitivity to inhibition of protein synthesis by DT, in agreement with the six- to sevenfold induction of HB-EGF mRNA expression in this cell type following induction of $\mathrm{H}-\mathrm{Ras}(\mathrm{V} 12)$. A nontoxic form of DT, CRM
197 , which acts as a competitive inhibitor of DT binding to the transmembrane HB-EGF precursor (Pappenheimer 1977), protected cells expressing H-Ras(V12) from inhibition of protein synthesis by DT (Fig. 7C). Thus, increased sensitivity of Ras-transformed cells to DT can be accounted for, at least in part, by the induced expression of the transmembrane HB-EGF precursor on the cell surface.

\section{Discussion}

It is abundantly clear that the Ras/Raf/MEK/MAP kinase pathway plays an important role in the initiation of cellular proliferation, differentiation, and oncogenic transformation (Marshall 1995). Cellular responses to these signaling proteins are thought to be manifested, at least in part, through modulation of gene expression. The availability of conditional forms of Raf kinases provides a unique opportunity to identify direct target genes of the Ras/Raf/MEK/MAP kinase cascade. Using $\triangle$ Raf1 :ER (Samuels et al. 1993) in combination with the sensitive technique of differential display PCR (Liang and Pardee 1992; Liang et al. 1993), we have identified HB- 
EGF as a direct transcriptional target of oncogenic Raf kinases.

HB-EGF mRNA expression was induced rapidly by $\Delta$ Raf-1:ER and $\triangle \mathrm{B}$-Raf:ER in NIH-3T3 cells in the absence of de novo protein synthesis. Elevated HB-EGF mRNA expression resulted from increased gene transcription rather than increased mRNA stability, suggesting that elements in the promoter region of the HB-EGF gene may be directly targeted by the signaling machinery downstream of Raf kinases. Analysis of the Raf responsiveness of the HB-EGF promoter should provide novel insights into the regulation of gene expression by the Ras/Raf/MEK/MAP kinase cascade. Our results suggest that the mechanism of regulation of HB-EGF expression by Raf kinases may vary between cell types. Activation of HB-EGF mRNA expression in Rat la cells was delayed relative to NIH-3T3 cells. Like NIH-3T3 cells, Ratla cells undergo oncogenic transformation following activation of $\Delta$ Raf-1:ER. However, $\Delta$ Raf-1:ER-dependent transformation of Ratla cells occurs in the absence of detectable MAP kinase activation (Samuels et al. 1993). It is therefore possible that a MAP kinase-independent signaling pathway that leads to stimulation of HB-EGF mRNA expression emanates from $\triangle \mathrm{Raf}-1$ :ER in this cell type. Cell-type differences in $\Delta$ Raf-1:ER-stimulated HBEGF mRNA expression have also been suggested by our studies of other cell lines. For example, despite robust activation of the MAP kinases in both the pro-B cell line, $\mathrm{Ba} / \mathrm{F} 3$, and the macrophage cell line RAW 264.7 (Hambleton et al. 1995), HB-EGF mRNA expression is activated by $\Delta$ Raf-1:ER only in the latter cell type (S. McCarthy, J. Hambleton, T. Kinoshita, and N. Sato, unpubl.).

Increased expression of $\mathrm{HB}-\mathrm{EGF}$ mRNA in response to $\Delta$ Raf-1:ER activation resulted in increased secretion of mature HB-EGF protein from cells. Although activation of $\Delta$ Raf-1:ER consistently resulted in an 8- to 10-fold induction of HB-EGF mRNA expression, only a 3- to 4-fold increase in secretion of mature HB-EGF protein was observed in conditioned media, suggesting that multiple mechanisms may serve to regulate HB-EGF protein secretion and re-uptake (Raab et al. 1994). Conditioned media from $\Delta$ Raf-1:ER or $\Delta \mathrm{B}$-Raf:ER-transformed cells elicited coordinate activation of the MAP kinases and JNKs when applied to naive NIH-3T3 cells. That HBEGF was necessary for this activity was shown by depletion of the activity from conditioned media with heparin-Sepharose and neutralization of the activity with specific anti-HB-EGF antibodies, but not by preimmune control antiserum. Moreover, we demonstrated comparable MAP kinase activation in NIH-3T3 and HeLa cells by a concentration of recombinant human HB-EGF equivalent to that estimated to be present in the conditioned media of $\Delta$ Raf-1:ER-transformed cells. Thus, $\mathrm{HB}-$ EGF secretion appears necessary and sufficient for autocrine activation of the JNKs in Raf-transformed cells. In 3T3 3 Raf-1:ER cells anti-HB-EGF antibodies blocked JNK activation but had no effect on MAP kinase activation. We interpret these data to indicate that $\triangle \mathrm{Raf}-1: \mathrm{ER}$ activates the JNKs via autocrine HB-EGF, which signals through the EGF receptor, whereas MAP kinase activity is maintained by the direct action of $\triangle$ Raf-1:ER on MEK. These data are in accord with recent data indicating a lack of direct cross talk between the MAP kinase and JNK pathways (Minden et al. 1994a; Sanchez et al. 1994; Yan et al. 1994) and underscore the utility of conditional systems such as $\triangle$ Raf:ER fusion proteins in the dissection of temporal interplay between intracellular signaling pathways.

Elaboration of autocrine growth factors, including members of the EGF family, is widely recognized as a hallmark of the transformed state (DeLarco and Todaro 1978; Aaronson 1991). However, the mechanisms that lead to increased growth factor expression remain poorly characterized (Baserga 1994). To our knowledge the present study constitutes one of the clearest examples of direct transcriptional activation of growth factor expression by an oncogene. We have also shown that oncogenic Ras stimulates HB-EGF mRNA expression. Whether HB-EGF induction contributes to the oncogenic potential of Ras and Raf is unclear. Although several reports have implicated autocrine factors, including members of the EGF family, in oncogenic transformation (Stern et al. 1987; Ciardiello et al. 1988, 1990; Heidaran et al. 1990; Filmus et al. 1993; Brunet et al. 1994; Cowley et al. 1994) we have thus far been unable to demonstrate a role for HB-EGF secretion in transformation by $\triangle$ Raf-1:ER or $\mathrm{H}$-Ras(V12). In addition to HB-EGF, however, we have also identified a number of other $\Delta$ Raf-1:ER-regulated genes. The concerted actions of these and other genes is likely to be required to elicit full oncogenic transformation.

We have also shown that induction of HB-EGF expression by Ras and Raf oncogenes predisposes cells to the cytotoxic action of DT, for which the transmembrane HB-EGF precursor acts as a cell-surface receptor (Naglich et al. 1992a; Iwamoto et al. 1994|. Ratl cells induced to express H-Ras(V12) were found to be at least 50 times more sensitive to killing by DT than control cells. This finding is in accord with several reports that document increased sensitivity of transformed cells to DT relative to their normal counterparts (Buzzi and Maistrello 1973; Iglewski and Rittenberg 1974; Iglewski et al. 1975; Taylor and Iglewski 1979). Cells expressing H-Ras(V12) were six times more sensitive to inhibition of protein synthesis by DT than control cells, and sensitivity was blocked by a competitive antagonist of DT binding to its receptor. Thus, increased receptor-dependent toxin uptake accounts, in part, for increased DT sensitivity of cells expressing oncogenic Ras. These studies provide a potential molecular mechanism for increased DT sensitivity in oncogene-transformed cells. Although it is unclear if $\mathrm{HB}-\mathrm{EGF}$ is overexpressed in the transformed cell lines shown previously to be sensitive to DT, it should be noted that HB-EGF mRNA is frequently overexpressed in human pancreatic carcinoma, in which activating mutations in Ras are extremely prevalent (Bos 1989; Kobrin et al. 1994). HB-EGF has also been shown recently to be overexpressed in human hepatocellular carcinoma (Inui et al. 1994). Our findings 
may therefore be of direct relevance to certain human cancers.

\section{Materials and methods}

\section{Materials}

All radiochemicals were purchased from Amersham. DT, cycloheximide, actinomycin- $D$, and $\beta$-estradiol were purchased from Sigma. Human HB-EGF was purchased from R\&D systems (Minneapolis, MN). CRM 197 was purchased from Berna Products Corp. (FL). ICI 164,384 was a gift of Dr. Alan Wakeling (Zeneca Pharmaceuticals, Macclesfield, Cheshire, UK).

\section{Cell culture}

The generation of $3 T 3 \Delta$ Raf-1:ER, Ratla $\Delta$ Raf-1:ER, 3T3 $\Delta$ ARaf:ER, and 3T3 BB-Raf:ER cell lines has been described elsewhere (Samuels et al. 1993; C.A. Pritchard, M.L. Samuels, E. Borsch, and M. McMahon, in prep.). 3T3:iRas and Ratl:iRas cells were a generous gift from Hiroshi Itoh and Yoshito Kaziro (Tokyo Institute of Technology, Japan). Cell lines were maintained as described previously (Samuels et al. 1993; Samuels and McMahon 1994).

\section{Differential display PCR}

Total RNA was isolated from appropriately treated cells by use of RNeasy columns from Qiagen. DNA contamination was removed from RNAs to be used in differential display PCR reactions by use of the Message Clean Kit (Genhunter, Brookline, MA). Differential display PCR reactions were performed by use of the RNAmap kit (Genhunter). PCR amplifications were performed by use of a Perkin-Elmer 9600 GeneAmp system. PCR products were cloned into the pCRII vector by use of the TA Cloning Kit (Invitrogen) and sequenced with Sequenase (Amersham). For 14G1, sequencing of plasmid DNA from $10 \mathrm{mini}-$ preps revealed three distinct cDNA inserts. Of these, HB-EGF was represented six times and therefore subjected to further analysis by RNase protection.

\section{RNase protection}

RNase protection assays were performed as described previously (Ausubel et al. 1987; McCarthy and Bicknell 1992). The 14Gl riboprobe was prepared by transcription of a XhoI-linearized plasmid template, containing the 263-bp 14G1 insert, with SP6 RNA polymerase. The HB-EGF riboprobe was prepared by SP6 transcription of an EcoRV-linearized plasmid template, containing the 627-bp-coding region of the murine HB-EGF cDNA, which was obtained by PCR amplification from firststrand cDNA prepared from NIH-3T3 cells with the oligonucleotide primers $5^{\prime}$-ATGAAGCTGCTGCCGTCGGT-3' and 5'GCGTGGCTAGCTCCCACTGA-3'. Assays were quantitated with a Molecular Dynamics PhosphorImager.

\section{Run-on transcription assays}

$3 T 3 \Delta$ B-Raf:ER cells were made quiescent by overnight incubation in medium containing $0.5 \%$ fetal calf serum and treated with either $0.1 \%(\mathrm{vol} / \mathrm{vol})$ ethanol as a solvent control or $1 \mu \mathrm{M}$ ICI for $3 \mathrm{hr}$. Nuclei were isolated and runoff transcripts labeled by standard methods (Ausubel et al. 1987). Labeled transcripts were subsequently purified with RNeasy columns (Qiagen) and hybridized to filter-immobilized plasmid DNAs.

\section{Preparation of conditioned media}

Conditioned media were collected from confluent monolayers of $3 T 3 \Delta$ Raf-1:ER or $3 T 3 \Delta B-R a f: E R$ cells that were maintained for $36 \mathrm{hr}$ in Dulbecco's modified Eagle medium (DMEM) containing $0.5 \%$ fetal calf serum (FCS), in the absence or presence of $1 \mu \mathrm{M}$ ICI as appropriate. For heparin depletion, $100 \mu \mathrm{l}$ of reconstituted heparin-Sepharose beads (Pharmacia) were added to $1.5 \mathrm{ml}$ of conditioned media and the samples rotated overnight at $4^{\circ} \mathrm{C}$. Nondepleted media were also rotated overnight at $4^{\circ} \mathrm{C}$. For antibody neutralizations, $1.5-\mathrm{ml}$ samples of conditioned media were mixed with $100 \mu \mathrm{l}$ of antibodies and incubated overnight at $4^{\circ} \mathrm{C}$. The antibodies used were antiserum 197 (goat anti-human HB-EGF; $1 \mathrm{mg} / \mathrm{ml}$ ), antiserum 19 (goat antirat $\mathrm{HB}-\mathrm{EGF} ; 45.2 \mathrm{mg} / \mathrm{ml})$, or preimmune goat antiserum $(31.3$ $\mathrm{mg} / \mathrm{ml}$ ). Prior to application to naive cells media from control cells were supplemented with $1 \mu \mathrm{M}$ ICI.

\section{MAP kinase and INK assays}

p42 MAP kinase and JNK activities were measured as described previously (Samuels et al. 1993; Minden et al. 1994a; Samuels and McMahon 1994).

\section{Metabolic labeling and two-dimensional polyacrylamide gel electrophoresis}

Confluent monolayers of $3 \mathrm{~T} 3 \Delta \mathrm{Raf}-1: \mathrm{ER}$ cells were treated with either $0.1 \%(\mathrm{vol} / \mathrm{vol})$ ethanol as a solvent control or $1 \mu \mathrm{M} \mathrm{ICI}$ for $1 \mathrm{hr}$, at which time the cells were pulsed with $\left[{ }^{35} \mathrm{~S} \mid\right.$ methionine/ cysteine Translabel $(0.5 \mathrm{mCi} / \mathrm{ml})$ for $6 \mathrm{hr}$ in methionine- and cysteine-free DMEM containing 10\% dialyzed FCS. Labeled proteins were chased from the cells by incubation in serum-free DMEM for a further $19 \mathrm{hr}$. Samples of ethanol-precipitated material $(50 \mu \mathrm{g})$ were subjected to two-dimensional polyacrylamide gel electrophoresis (O'Farrell, 1975) by Kendrick Labs Inc. (Madison, WI).

\section{Measurement of cellular protein synthesis}

Protein synthesis was measured by uptake of $\left[{ }^{3} \mathrm{H}\right]$ leucine. Confluent monolayers of Rat $1:$ iRas cells were trypsinized and cells plated onto 96 -well plates $(\sim 10,000$ cells per well $)$ in the absence or presence of $5 \mathrm{~mm}$ IPTG. After a further 24-hr incubation, cells were treated with serial dilutions of DT in the continued absence or presence of IPTG. Cells were incubated for an additional $14 \mathrm{hr}$, the medium removed and replaced with leucine-free DMEM (GIBCO) supplemented with 5\% FCS, and 8.5 $\mu \mathrm{Ci} / \mathrm{ml}\left[{ }^{3} \mathrm{H}\right]$ leucine. After a 2-hr incubation incorporation of $\left[{ }^{3} \mathrm{H}\right]$ leucine was measured by the harvesting of cells onto glass fiber filters with a Skatron 96-well cell harvester and counting in a Betaplate 1205 liquid scintillation counter.

\section{Acknowledgments}

We thank Jorge Guimaraes for encouragement and advice concerning differential display PCR. We are especially grateful to Audrey Minden and Michael Karin for initial discussions and pGEXc-Jun. We thank Hiroshi Itoh and Yoshito Kaziro for 3T3:iRas and rat 1:iRas cell lines, Brett Garrick for goat anti-rat HB-EGF and preimmune antisera, Debbie Damm for the goat anti-human HB-EGF antisera, Michael Klagsbrun for a mouse HB-EGF cDNA clone, Stephanie Wright and Rene DeWaal Malefyt for advice on run-on transcription assays, and Mary 
Weiss, Satish Menon, and Gerard Zurawski for expert assistance with protein purification. We also thank Emma Lees, Kevin Moore, Michael Klagsbrun, and Michael Karin for critical review of the manuscript and Elizabeth Bosch, Natasha Aziz, and Douglas Woods for encouragement, helpful comments, and discussion. This work was supported in part by a Small Business Innovation Research Grant GM46166 (to J.A.A.). The DNAX Research Institute is supported by Schering Plough Corporation.

The publication costs of this article were defrayed in part by payment of page charges. This article must therefore be hereby marked "advertisement" in accordance with 18 USC section 1734 solely to indicate this fact.

\section{References}

Aaronson, S.A. 1991. Growth factors and cancer. Science 254: 1146-1153.

Abraham, J.A., D. Damm, A. Bajardi, J. Miller, M. Klagsbrun, and R.A. Ezekowitz. 1993. Heparin-binding EGF-like growth factor: Characterization of rat and mouse cDNA clones, protein domain conservation across species, and transcript expression in tissues. Biochem. Biophys. Res. Commun. 190: $125-133$.

Almendral, J.M., D. Sommer, H. MacDonald-Bravo, J. Burckhardt, J. Perera, and R. Bravo. 1988. Complexity of the early genetic response to growth factors in fibroblasts. Mol. Cell. Biol. 8: 2140-2148.

Ausubel, F.M., R. Brent, R.E. Kingston, D.D. Moore, J.G. Seidman, J.A. Smith, and K. Struhl. 1987. Current protocols in molecular biology. John Wiley and Sons, New York.

Barnard, J.A., R. Graves-Deal, M.R. Pittelkow, R. Du Bois, P. Cook, G.W. Ramsey, P.R. Bishop, L. Damstrup, and R.J. Coffey. 1994. Auto- and cross-induction within the mammalian epidermal growth factor-related peptide family. I. Biol. Chem. 269: 22817-22822.

Baserga, R. 1994. Oncogenes and the strategy of growth factors. Cell 79: 927-930.

Blotnick, S., G.E. Peoples, M.R. Freeman, T.J. Eberlein, and M. Klagsbrun. 1994. T lymphocytes synthesize and export heparin-binding epidermal growth factor-like growth factor and basic fibroblast growth factor, mitogens for vascular cells and fibroblasts: Differential production and release by CD4 + and CD8 + T cells. Proc. Natl. Acad. Sci. 91: 28902894.

Bos, J.L. 1989. Ras oncogenes in human cancer: A review. Cancer Res. 49: 4682-4689.

Brunet, A., G. Pages, and J. Pouyssegur. 1994. Constitutively active mutants of MAP kinase kinase (MEK1) induce growth factor relaxation and oncogenicity when expressed in fibroblasts. Oncogene 9: 3379-3387.

Brunner, D., K. Ducker, N. Oellers, E. Hafen, H. Scholz, and C. Klambt. 1994. The ETS domain protein pointed-P2 is a target of MAP kinase in the sevenless signal transduction pathway. Nature 370: 386-389.

Buzzi, S. and I. Maistrello. 1973. Inhibition of growth of Erlich tumours in Swiss mice by diphtheria toxin. Cancer Res. 33: 2349-2353.

Ciardiello, F., N. Kim, N. Hynes, R. Jaggi, S. Redmond, D.S. Liscia, B. Sanfilippo, G. Merlo, R. Callahan, and W.R. Kidwell. 1988. Induction of transforming growth factor alpha expression in mouse mammary epithelial cells after transformation with a point-mutated c-Ha-ras protooncogene. Mol. Endocrinol. 2: 1202-1216.

Ciardiello, F., M.L. McGeady, N. Kim, F. Basolo, N. Hynes, B.C. Langton, H Yokozaki, T. Saeki, J.W. Elliott, and H. Masui.
1990. Transforming growth factor-alpha expression is enhanced in human mammary epithelial cells transformed by an activated c-Ha-ras protooncogene but not by the c-neu protooncogene, and overexpression of the transforming growth factor-alpha complementary DNA leads to transformation. Cell Growth Differ. 1: 407-420.

Cowley, S., H. Paterson, P. Kemp, and C.J. Marshall. 1994. Activation of MAP Kinase Kinase is necessary and sufficient for PC12 differentiation and for transformation of NIH 3T3 cells. Cell 77: 841-852.

De Larco, J.E. and G.J. Todaro. 1978. Growth factors from murine sarcoma virus-transformed cells. Proc. Natl. Acad. Sci. 75: 4001-4005.

Derijard, B., M. Hibi, I. Wu, T. Barrett, B. Su, T. Deng, M. Karin, and R.J. Davis. 1994. JNK1: A protein kinase stimulated by UV light and Ha-ras that binds and phosphorylates the c-jun activation domain. Cell 76: 1025-1037.

Dickson, B. and E. Hafen. 1994. Genetics of signal transduction in invertebrates. Curr. Opin. Genet. Dev. 4: 64-70.

Dluz, S.M., S. Higashiyama, D. Damm, J.A. Abraham, and M. Klagsbrun. 1993. Heparin-binding epidermal growth factorlike growth factor expression in cultured fetal human vascular smooth muscle cells. Induction of mRNA levels and secretion of active mitogen. $J$. Biol. Chem. 268: 1833018334.

Egan, S.E. and R.A. Weinberg. 1993. The pathway to signal achievement. Nature 365: 781-783.

Filmus, J., W. Shi, and T. Spencer. 1993. Role of transforming growth factor alpha in the transformation of ras-transfected rat intestinal epithelial cells. Oncogene 8: 1017-1022.

Gallego, C., S.K. Gupta, L.E. Heasley, N.X. Qian, and G.L. Johnson. 1992. Mitogen-activated protein kinase activation resulting from selective oncogene expression in NIH 3T3 and rat la cells. Proc. Natl. Acad. Sci. 89: 7355-7359.

Gupta, S., D. Campbell, B. Derijard, and R.J. Davis. 1995. Transcription factor ATF-2 regulation by the INK signal transduction pathway. Science 267: 389-393.

Gupta, S.K., C. Gallego, G.L. Johnson, and L.E. Heasley. 1992. MAP kinase is constitutively activated in gip2 and src transformed ratla fibroblasts. $J$. Biol. Chem. 267: 7987-7990.

Hambleton, J., M. McMahon, and A.L. DeFranco. 1995. Activation of Raf-l and mitogen activated protein kinase in murine macrophages partially mimics lipopolysaccharide-induced signaling events. J. Exp. Med. 182: 147-154.

Hashimoto, K., S. Higashiyama, H. Asada, E. Hashimura, T. Kobayashi, K. Sudo, T. Nakagawa, D. Damm, K. Yoshikawa, and N. Taniguchi. 1994. Heparin-binding epidermal growth factor-like growth factor is an autocrine growth factor for human keratinocytes. J. Biol. Chem. 269: 20060-20066.

Heidaran, M.A., T.P. Fleming, D.P. Bottaro, G.I. Bell, P.P. Di Fiore, and S.A. Aaronson. 1990. Transformation of NIH3T3 fibroblasts by an expression vector for the human Epidermal Growth Factor precursor. Oncogene 5: 1265-1270.

Herschman, H.R. 1991. Primary response genes induced by growth factors and tumor promoters. Annu. Rev. Biochem. 60: 281-319.

Herskowitz, I. 1995. MAP kinase pathways in yeast: For mating and more. Cell 80: 187-197.

Hibi, M., A. Lin, T. Smeal, A. Minden, and M. Karin. 1993. Identification of an oncoprotein- and UV-responsive protein kinase that binds and potentiates the c-Jun activation domain. Genes \& Dev. 7: 2135-2148.

Higashiyama, S., J.A. Abraham, J. Miller, J.C. Fiddes, and M. Klagsbrun. 1991. A heparin-binding growth factor secreted by macrophage-like cells that is related to EGF. Science 251: 936-939. 
Higashiyama, S., K. Lau, G.E. Besner, J.A. Abraham, and M. Klagsbrun. 1992. Structure of heparin-binding EGF-like growth factor. Multiple forms, primary structure, and glycosylation of the mature protein. J. Biol. Chem. 267: 62056212.

Higashiyama, S., J.A. Abraham, and M. Klagsbrun. 1993. Heparin-binding EGF-like growth factor stimulation of smooth muscle cell migration: Dependence on interactions with cell surface heparan sulfate. J. Cell Biol. 122: 933-940.

Hill, C.S. and R. Treisman. 1995. Transcriptional regulation by extracellular signals: Mechanisms and specificity. Cell 80: $199-211$.

Hill, C.S., R. Marais, S. John, J. Wynne, S. Dalton, and R. Treisman. 1993. Functional analysis of a growth factor-responsive transcription factor complex. Cell 73: 395-406.

Hunter, T. and M. Karin. 1992. The regulation of transcription by phosphorylation. Cell 70: 375-387.

Iglewski, B.H. and M.B. Rittenberg. 1974. Selective toxicity of diphtheria toxin for malignant cells. Proc. Natl. Acad. Sci. 71: 2707-2710.

Iglewski, B.H., M.B. Rittenberg, and W.J. Iglewski. 1975. Preferential inhibition of growth and protein synthesis in Rous sarcoma virus transformed cells by diphtheria toxin. Virology 65: 272-275.

Inui, Y., S. Higashiyama, S. Kawata, S. Tamura, J. Miyagawa, N. Taniguchi, and Y. Matsuzawa. 1994. Expression of heparinbinding epidermal growth factor in human hepatocellular carcinoma. Gastroenterology 107: 1799-1804.

Ito, N., S. Kawata, S. Tamura, S. Kiso, H. Tsushima, D. Damm, J.A. Abraham, S. Higashiyama, N. Taniguchi, and Y. Matsuzawa. 1994. Heparin-binding EGF-like growth factor is a potent mitogen for rat hepatocytes. Biochem. Biophys. Res. Commun. 198: 25-31.

Iwamoto, R., S. Higashiyama, T. Mitamura, N. Taniguchi, M. Klagsbrun, and E. Mekada. 1994. Heparin-binding EGF-like growth factor, which acts as the diphtheria toxin receptor, forms a complex with membrane protein DRAP27/CD9, which up-regulates functional receptors and diphtheria toxin sensitivity. EMBO J. 13: 2322-2330.

Karin, M. 1994. Signal transduction from the cell surface to the nucleus through the phosphorylation of transcription factors. Curr. Opin. Cell Biol. 6: 415-424.

Kobrin, M.S., H. Funatomi, H. Friess, M.W. Buchler, P. Stathis, and M. Korc. 1994. Induction and expression of heparinbinding EGF-like growth factor in human pancreatic cancer. Biochem. Biophys. Res. Commun. 202: 1705-1709.

Kyriakis, J.M., P. Baneriee, E. Nikolakaki, T. Dai, E.A. Rubie, M.F. Ahmad, J. Avruch, and J.R. Woodgett. 1994. The stress activated protein kinase subfamily of $\mathrm{c}$-jun kinases. Nature 369: 156-160.

Lange-Carter, C.A. and G.L. Johnson. 1994. Ras-dependent growth factor regulation of MEK kinase in PC12 cells. Science 265: 1458-1461.

Lange-Carter, C.A., C.M. Pleiman, A.M. Gardner, K.J. Blumer, and G.L. Johnson. 1993. A divergence in the MAP kinase regulatory network defined by MEK kinase and Raf. Science 260: 315-319.

Liang, P. and A. Pardee. 1992. Differential display of eukaryotic messenger RNA by means of the polymerase chain reaction. Science 257: 967-971.

Liang, P., L. Averboukh, and A.B. Pardee. 1993. Distribution and cloning of eukaryotic mRNAs by means of differential display: Refinements and optimization. Nucleic Acids Res. 21: 3269-3275.

Marais, R., J. Wynne, and R. Treisman. 1993. The SRF accessory protein Elk-1 contains a growth factor-regulated transcrip- tional activation domain. Cell 73: 381-394.

Marshall, C.J. 1994. MAP kinase kinase kinase, MAP kinase kinase and MAP kinase. Curr. Opin. Genet. Dev. 4: 82-89.

1995. Specificity of receptor tyrosine kinase signaling: transient versus sustained extracellular signal-regulated kinase activation. Cell 80: 179-185.

McCarthy, S.A. and R.B. Bicknell. 1992. Responses of pertussis toxin-treated microvascular endothelial cells to transforming growth factor beta. J. Biol. Chem. 267: 21617-21622.

Middlebrook, J.L. and R.B. Dorland. 1984. Bacterial toxins: Cellular mechanisms of action. Microbiol. Rev. 48: 199-221.

Minden, A., A. Lin, M. McMahon, C. Lange-Carter, B. Derijard, R.J. Davis, G.L. Johnson, and M. Karin. 1994a. Differential activation of ERK and JNK mitogen-activated protein kinases by Raf- 1 and MEKK. Science 266: 1719-1723.

Minden, A., A. Lin, T. Smeal, B. Derijard, M. Cobb, R. Davis, and M. Karin. 1994b. c-jun N-terminal phosphorylation correlates with activation of the JNK subgroup but not the ERK subgroup of mitogen activated protein kinases. Mol. Cell. Biol. 14: 6683-6688.

Morita, T., M. Yoshizumi, H. Kurihara, K. Maemura, R. Nagai, and Y. Yazaki. 1993. Shear stress increases heparin-binding epidermal growth factor-like growth factor mRNA levels in human vascular endothelial cells. Biochem. Biophys. Res. Commun. 197: 256-262.

Morrison, D.K. 1990. The Raf-1 kinase as a transducer of mitogenic signals. Cancer Cells 2: 377-382.

Naglich, J.G., J.E. Metherall, D.W. Russell, and L. Eidels. 1992a. Expression cloning of a diphtheria toxin receptor: Identity with a heparin-binding EGF-like growth factor precursor. Cell 69: 1051-1061.

Naglich, J.G., J.M. Rolf, and L. Eidels. 1992b. Expression of functional diphtheria toxin receptors on highly sensitive mouse cells that specifically bind radioiodinated toxin. Proc. Natl. Acad. Sci. 89: 2170-2174.

Nakano, T., E.W. Raines, J.A. Abraham, M. Klagsbrun, and R. Ross. 1994. Lysophosphatidylcholine upregulates the level of heparin-binding epidermal growth factor-like growth factor mRNA in human monocytes. Proc. Natl. Acad. Sci. 91: 1069-1073.

Nakano, T., E.W. Raines, J.A. Abraham, F. Wenzel, S. Higashiyama, M. Klagsbrun, and R. Ross. 1993. Glucocorticoid inhibits thrombin-induced expression of platelet-derived growth factor A-chain and heparin-binding epidermal growth factor-like growth factor in human aortic smooth muscle cells. J. Biol. Chem. 268: 22941-22947.

Nishida, E. and Y. Gotoh. 1993. The MAP kinase cascade is essential for diverse signal transduction pathways. Trends Biochem. Sci. 18: 128-131.

O'Farrell, P.H. 1975. High resolution two-dimensional electrophoresis of proteins. J. Biol. Chem. 250: 4007-4021.

O'Neill, E.M., I. Rebay, R. Tijan, and G.M. Rubin. 1994. The activities of two ets-related transcription factors required for Drosophila eye development are modulated by the ras/ MAPK pathway. Cell 78: 137-147.

Pappenheimer, A.M. 1977. Diphtheria toxin. Annu. Rev. Biochem. 46: 69-94.

Perrella, M.A., T. Maki, S. Prasad, D. Pimental, K. Singh, N. Takahashi, M. Yoshizumi, A. Alali, S. Higashiyama, and R.A. Kelly. 1994. Regulation of heparin-binding epidermal growth factor-like growth factor mRNA levels by hypertrophic stimuli in neonatal and adult rat cardiac myocytes. $/$. Biol. Chem. 269: 27045-27050.

Raab, G., S. Higashiyama, S. Hetelekidis, J.A. Abraham, D. Damm, M. Ono, and M. Klagsbrun. 1994. Biosynthesis and processing by phorbol ester of the cells surface-associated 


\section{McCarthy et al.}

precursor form of heparin-binding EGF-like growth factor. Biochem. Biophys. Res. Commun. 204: 592-597.

Rapp, U.R. 1991. Role of Raf-1 serine/threonine protein kinase in growth factor signal transduction. Oncogene 6: 495-500.

Rebay, I. and G.M. Rubin. 1995. Yan functions as a general inhibitor of differentiation and is negatively regulated by activation of the Rasl/MAPK pathway. Cell 81: 857-866.

Russell, M., C.A. Lange-Carter, and G.L. Johnson. 1995. Direct interaction between Ras and the kinase domain of mitogenactivated protein kinase kinase kinase (MEKK1). I. Biol. Chem. 270: 11757-11760.'

Samuels, M.L., M.J. Weber, J.M. Bishop, and M. McMahon. 1993. Conditional transformation of cells and rapid activation of the mitogen-activated protein kinase cascade by an estradiol-dependent human raf-l protein kinase. Mol. Cell. Biol. 13: 6241-6252.

Samuels, M.L. and M. McMahon. 1994. Inhibition of PDGF and EGF-mediated mitogenesis and signaling in $3 \mathrm{~T} 3$ cells expressing $\triangle \mathrm{Raf}-1: \mathrm{ER}$, an estradiol-regulated form of Raf-1. Mol. Cell. Biol. 14: 7855-7866.

Sanchez, I., R.T. Hughes, B.J. Mayer, K. Yee, J.R. Woodgett, J. Avruch, J.M. Kyriakis, and L.I. Zon. 1994. Role of SAPK/ ERK kinase- 1 in the stress activated pathway regulating transcription factor c-jun. Nature 372: 794-798.

Stern, D.F., D.L. Hare, M.A. Cecchini, and R.A. Weinberg. 1987. Construction of a novel oncogene based on synthetic sequences encoding Epidermal Growth Factor. Science 235: 321-324.

Sternberg, P.W., A. Golden, and M. Han. 1993. Role of a raf proto-oncogene during Caenorhabditis elegans vulval development. Phil. Trans. R. Soc. Lond. 340: 259-265.

Su, B., E. Jacinto, M. Hibi, T. Kallunki, M. Karin, and Y. BenNeriah. 1994. JNK is involved in signal integration during co-stimulation of T lymphocytes. Cell 77: 727-736.

Tan, M.S., Y.J. Lee, S.J. Shin, and J.H. Tsai. 1994. Regulation of heparin binding-epidermal growth factor like growth factor gene expression by LDL and oxidized-LDL in rat mesangial cells. Biochem. Biophys. Res. Commun. 202: 1001-1008.

Taylor, A. and W.J. Iglewski. 1979. Intoxication of normal and virus transformed cells by diphtheria toxin. Virology 96: $177-185$.

Temizer, D.H., M. Yoshizumi, M.A. Perrella, E.E. Susanni, T. Quertermous, and M.E. Lee. 1992. Induction of heparinbinding epidermal growth factor-like growth factor mRNA by phorbol ester and angiotensin II in rat aortic smooth muscle cells. J. Biol. Chem. 267: 24892-24896.

Yan, M., T. Dai, J.C. Deak, J.M. Kyriakis, L.I. Zon, J.R. Woodgett, and D.J. Templeton. 1994. Activation of stress activated protein kinase by MEKKl phosphorylation of its activator SEK1. Nature 372: 798-800.

Yoshizumi, M., S. Kourembanas, D.H. Temizer, R.P. Cambria, T. Quertermous, and M.E. Lee. 1992. Tumor necrosis factor increases transcription of the heparin-binding epidermal growth factor-like growth factor gene in vascular endothelial cells. J. Biol. Chem. 267: 9467-9469. 


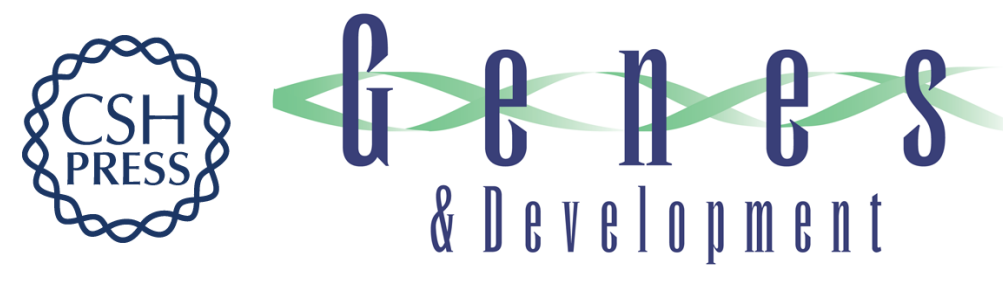

\section{Rapid induction of heparin-binding epidermal growth factor/diphtheria toxin receptor expression by Raf and Ras oncogenes.}

S A McCarthy, M L Samuels, C A Pritchard, et al.

Genes Dev. 1995, 9:

Access the most recent version at doi:10.1101/gad.9.16.1953

References This article cites 79 articles, 37 of which can be accessed free at: http://genesdev.cshlp.org/content/9/16/1953.full.html\#ref-list-1

License

Email Alerting

Receive free email alerts when new articles cite this article - sign up in the box at the top Service right corner of the article or click here.

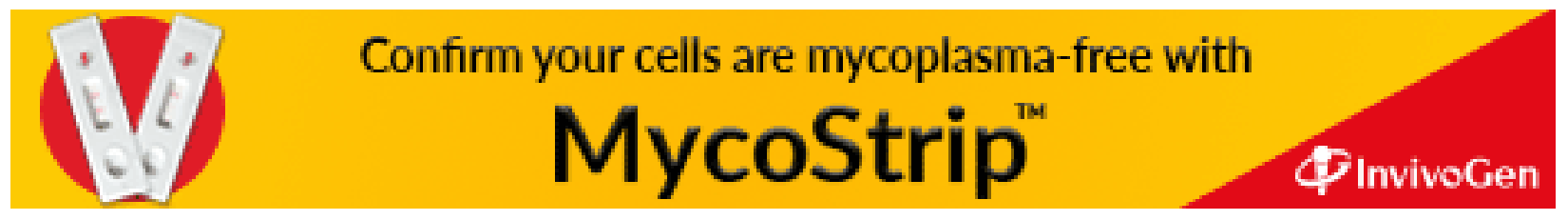

